\title{
Die ontstaan van belydenisskrifte gedurende die sestiende en sewentiende eeu
}

Wim Dreyer

Tydelik-deeltydse dosent: Departement Kerkgeskiedenis (Afd A)

Universiteit van Pretoria

\begin{abstract}
The origin of Reformed confessions during the sixteenth and seventeenth centuries

This article examins the background, history and development of Reformed confessions in the sixteenth and seventeenth centuries, but especially the Swiss and French confessions which influenced the Belgic Confession of Faith, the Heidelberg Catechism and the Articles of Dordt. The premise is that if we really want to understand and interpret confessions, they must be read against their historical, theological and political background. At the same time confessions cannot be properly understood in isolation from their present context, that is, being confessions of the church. Confessions are not only historical documents, but of immense importance to the church which must confess its faith in the present.
\end{abstract}

\section{INLEIDING}

Op 31 Oktober 1517 het Martin Luther sy 95 stellings teen die kerkdeur in Wittenberg vasgespyker. Dit word algemeen aanvaar dat dié optrede van Luther die begin van die Kerkhervorming verteenwoordig, alhoewel daar reeds voor Luther bepaalde kragte in die Europese samelewing aan die werk was wat die Kerkhervorming moontlik gemaak het. Tydens die Nasionale Sinode van die Nederlandse Hervormde Kerk te Dordrecht (1618/1619) is die Dordtse Leerreëls geformuleer, en dit kan as die afsluiting van die Kerkhervorming beskou word.

Die Kerkhervorming beslaan 'n tydperk van ongeveer 100 jaar (1517-1619). Dit was ' $n$ tyd van radikale en ingrypende verandering op kerklike, sosio-politieke en ekonomiese gebied (Dreyer 1995:11-13). Dit was ook 'n tyd van worsteling om tot 'n regte verstaan van die evangelie van Jesus Christus te kom. Hierdie worsteling om die Skrif en evangelie reg te verstaan, het daartoe aanleiding gegee dat die Reformatoriese kerke in Duitsland, Switserland, Frankryk, Hongarye, Engeland en Nederland talle belydenisskrifte geformuleer en gepubliseer het. Daar was verskeie redes waarom daar soveel belydenisskrifte ontstaan het: 
* Die verskillende Reformatoriese kerke het selfstandig van mekaar gefunksioneer. Dit beteken dat kerke in verskillende gebiede en lande belydenisskrifte opgestel het wat vir daardie gebied of land gegeld het.

* Die belydenisskrifte is gebore uit die nood van die prediking. Predikante in dieselfde gebied was dalk almal Reformatories gesind, maar het nie op 'n eenvormige wyse die evangelie verkondig nie. Die predikante wou duidelikheid hê oor wat hulle moes preek, en daarom was die belydenisskrifte pogings om die suiwere en ware leer, gegrond op die Bybel, ten dienste van die prediking te formuleer.

* Daar was behoefte aan geskrifte wat vir kategetiese onderrig gebruik kon word.

* Die blydenisskrifte was polemies gerig teen die wanpraktyke en dwaalleer van die Rooms-Katolieke Kerk.

* Die belydenisskrifte was apologetiese dokumente, gerig aan die owerhede, waarin die leer van die Reformatoriese kerke verdedig is. Dit was van eksistensiele belang vir hierdie kerke, omdat hulle op grond van die cuius regio eius religio beginsel deur die owerhede vervolg is (Dreyer 1995:30). Die owerhede en Rooms-Katolieke Kerk het in hierdie tydperk tienduisende Protetstante vervolg en om die lewe gebring.

Dit is opvallend dat die Lutherse kerke daarin geslaag het om die belydenisskrifte wat onder invloed van Luther ontstaan het, in 1580 te verenig in die Formula Concordiae (Bakhuizen vd Brink 1980:96). Die Calvinistiese kerke het nooit één belydenisskrif gehad nie, hoewel die verskillende nasionale kerke die belydenisskrifte wat hulle opgestel het, ook aan ander Calvinistiese kerke gestuur het vir kennisname en kommentaar. Francesco Salluardo het wel sy Harmonia confessionum in 1581 in Genève uitgegee waarin meeste van die Calvinistiese belydenisskrifte verwerk is - maar omdat dit die werk van een persoon was, is dit nooit as amptelike belydenisskrif aanvaar nie (Jahr 1964:13). Die gevolg was dat daar in verskillende gebiede verskillende belydenisskrifte gegeld het. Die belydenisskrif wat deur die meeste Calvinistiese kerke onderskryf is, is die Tweede Switserse Geloofsbelydenis van 1566. 
Die Nederduitsch Hervormde Kerk van Afrika aanvaar drie van die belydenisskrifte uit die Kerkhervorming as die Hervormde Kerk se belydenis, te wete die Nederlandse Geloofsbelydenis (1561), die Heidelbergse Kategismus (1563) en die Dordtse Leerreëls (1619). Dit staan ook bekend as die Drie Formuliere van Eenheid. Daarom is die Nederduitsch Hervormde Kerk nie net histories nie, maar ook wat sy leer en belydenis betref, aan die Kerkhervorming verbind.

Met die nagaan van die geskiedenis van die Kerkhervorming, word dit opeens duidelik dat die Drie Formuliere van Eenheid nie in isolasie ontstaan het nie, maar ingebed is in die sosio-politieke en kerklik-teologiese milieu van die sestiende eeu, en direk beïnvloed is deur die ander belydenisskrifte van dié eeu. Verskeie van hierdie belydenisskrifte is in die loop van die sestiende eeu saam gepubliseer - nie noodwendig as teenoorstaande belydenisskrifte nie, maar aanvullend tot mekaar (Jahr 1964:13). Daaruit blyk die interafhanklikheid en onderlinge invloed wat die belydenisskrifte op mekaar gehad het. Die verskillende belydenisskrifte kan beskou word as skakels in 'n ketting - elkeen het selfstandig ontstaan en gefunksioneer, maar het tog, veral inhoudelik, mekaar wedersyds beïnvloed (Jahr 1964:16).

Verskeie pogings is al angewend om die belangrikste belydenisskrifte in een bundel te versamel (vgl in die verband Cochrane 1966:11-32). Geen van hierdie versamelings is myns insiens volledig nie, omdat kerklike tradisie dikwels bepaal watter belydenisskrifte belangrik is en in 'n bundel opgeneem moet word. Kerklike en teologiese interesse bring noodwendig mee dat daar selektief met belydenisskrifte omgegaan word.

In hierdie studie word ook selektief te werk gegaan, omdat hier gepoog word om slegs enkele van die belangrikste belydenisskrifte te identifiseer wat in 'n historieskontinue lyn met die Drie Formuliere van Eenheid staan. Daar word dus net oorsigtelik gekyk na dié belydenisskrifte wat voor die Nederlandse Geloofsbelydenis en die Heidelbergse Kategismus ontstaan het. Die Dordtse Leerreëls is eiesoortig, in die opsig dat dit nie die reformatoriese leer volledig uiteensit nie, maar as gevolg van die Arminiaanse stryd op een leerstuk (die uitverkiesing) konsentreer.

Die doel van hierdie studie is om ' $n$ inleidende en historiese oorsig te gee van sommige belydenisskrifte wat in die sestiende en sewentiende eeu ontstaan het. Dit kan meehelp om die Drie Formuliere van Eenheid te verstaan en te interpreteer teen die agtergrond waarin hulle ontstaan het. Die belydenisskrifte is historiese dokumente wat binne hulle historiese konteks verstaan moet word. Die belangrikste belydenisskrifte wat die Nederlandse Geloofsbelydenis en die Heidelbergse Kategismus voorafgegaan het, is die volgende: 


\section{DIE SEWE-EN-SESTIG STELLINGS VAN 1523 (ZÜRICH)}

In Zürich het daar tussen predikante, kerkleiers en owerhede 'n dispuut ontwikkel oor die prediking van die evangelie (Jackson 1903:180). Die gevolg was dat Huldreich Zwingli sy Sewe-en-sestig Stellings vir bespreking voorberei het, met die oog op 'n dispuut (disputatio) van kerkleiers. Op 29 Januarie 1523 het die eerste dispuut plaasgevind. Seshonderd priesters, predikante, verteenwoordigers van die biskoppe, burgers en owerheidspersone het in die groot raadsaal in Zürich bymekaar gekom. Die Seween-sestig Stellings is bespreek, en aangesien die Rooms-Katolieke afvaardiging onder leiding van dr Faber nie uit die Bybel kon aantoon dat enige van Zwingli se stellings foutief is nie, is dit as norm vir die prediking in die kanton van Zürich aanvaar (Cochrane 1966:34).

Zwingli het na die eerste dispuut die stellings verder verfyn, en is die Sewe-ensestig Stellings in Julie 1523 afgehandel en gepubliseer. Daarna het ' $n$ tweede en derde dispuut gevolg, waarvan die resultaat was dat die Kerkhervorming in Zürich verder deurgevoer en deeglik gevestig is.

Wat die inhoud betref, was die Sewe-en-sestig Stellings aan die een kant gerig op die uiteensetting van die verlossing in en deur Jesus Christus, en aan die ander kant gemik teen die wanpraktyke in die Rooms-Katolieke Kerk (vgl die teks in Cochrane 1966:36-44). Besonder baie aandag word aan die misstande in die Rooms-Katolieke Kerk gegee, veral ten opsigte van die optrede van priesters - iets wat vanselfsprekend is omdat die stryd teen die Rooms-Katolieke wanpraktyke op hierdie stadium fel was en in die voorgrond gestaan het. Mettergaan sou hierdie polemiese motief van die belydenisskrifte op die agtergrond skuif (natuurlik nie volledig nie), en is daar meer en meer gekonsentreer op die uiteensetting van die ware geloof.

\section{DIE TIEN STELLINGS VAN 1528 (BERN)}

Die kerkhervorming in Bern het begin toe Berthold Haller in 1520 beroep is as kanon van die St. Vincent kerk. Hy het teologie aan die Universiteit van Keulen studeer, was bevriend met Melanchthon, en het in Bern teologie doseer van 1513 tot 1518. Rondom Haller het 'n evangeliese groep gevorm wat later groot steun van die owerheid geniet het. In 1523 het die Groot Raad van Bern die eerste Predigtmandat aanvaar waarin predikers toegelaat word om te preek oor tekste uit die Bybel (Cochrane 1966:45). In 1527 het Haller tien stellings geformuleer vir ' $n$ dispuut met verteenwoordigers van die Rooms-Katolieke Kerk. Uitnodigings is na al die Rooms-Katokieke universiteite en bisdomme gestuur om afgevaardigdes te stuur. Verskeie het die uitnodiging aanvaar, en op 6 Januarie 1528 het die dispuut plaasgevind. Die dispuut het 20 dae geduur, gekenmerk deur intense debat tussen die Rooms-Katolieke en Reformatoriese teoloë. 
Daar is noukeurig notule gehou van die verrigtinge, en dit is aan die owerheid oorhandig. Die owerheid van Bern het op 7 Februarie 1528 'n edik uitgevaardig en dit verpligtend vir alle predikante gemaak om die Tien Stellings te onderteken. Die edik het ook Rooms-Katolieke mis sowel as die magte van die biskoppe afgeskaf.

In die Tien Stellings word dit duidelik gestel dat die Woord die enigste bron en norm van die ware geloof is (sola scriptura); dat Jesus se offer aan die kruis die enigste voorwaarde vir verlossing is; dat Jesus Christus die enigste Middelaar tussen God en mens is; die vagevuur, beelde verering en selibaat word as onbybels afgemaak. Hieruit is dit duidelik dat die Tien Stellings die hart van die Rooms-Katolieke teologie aanval, en dat daar baie sterk Christosentries geredeneer word, gegrond op die Woord van God (vgl die teks in Cochrane 1966:49-50).

\section{DIE EERSTE BELYDENIS VAN 1534 (BASEL)}

Die persoon wat die meeste gedoen het om die Reformatoriese beginsels in Basel te laat posvat, was Johannes Oecolampadius. Hy is opgelei an die universiteite van Heidelberg en Tübingen, en is in 1522 as predikant in die St. Martins Kerk in Basel bevestig. Hoofsaaklik as gevolg van sy optrede, het die stadsowerheid op 9 Februarie 1529 die beginsels van die Reformasie deurgevoer, deurdat die Rooms-Katolieke mis, beeldediens en kloosterordes afgeskaf is. In 1531, terwyl hy reeds sterwend was, het hy 'n kort geloofsbelydenis aan die Sinode van Basel voorgelê. Sy opvolger, Oswald Myconius, het hierdie geloofsbelydenis verder verwerk, en dit is op 21 Januarie 1534 deur die stadsraad as belydenisskrif aanvaar (Cochrane 1966:89). Van 1534 tot 1872 was dit van elke predikant in Basel vereis om die Eerste Belydenis te onderteken.

Wat inhoud betref, is die Eerste Belydenis 'n kort samevatting van die evangeliese geloof in twaalf artikels. Dit is nie so sterk polemies gerig nie, maar bestry tog die Rooms-Katolieke leer ten opsigte van die nagmaal en die doopleer van die Anabaptiste. Dit is verder opvallend dat die artikels sterk klem lê op Jesus Christus as enigste Verlosser en dat die mens voorgestel word as totaal verlore in sy sonde. Verder word die Drie-eenheid en Christus se Goddelike en menslike natuur uiteengesit ( $\mathrm{vgl}$ die teks in Cochrane 1966:91-96).

\section{DIE LAUSANNE ARTIKELS VAN 1536 (LAUSANNE)}

Lausanne (soos Genève) was deel van Franssprekende Switserland, en sterk onder die invloed van Frankryk. In 1536 geluk dit die mense van Lausanne om met die behulp van die militêre mag van Bern die Franse oorheersing af te werp. Politieke bevryding het meegebring dat die Rooms-Katolieke Kerk se mag verbreek is en die owerheid het onmiddelik die Rooms-Katolieke mis afgeskaf en die Protestantse erediens ingevoer. Die leier van die reformasie in Lausanne was Guillaume Farel, Van 1 tot 8 Oktober 
1536 het 'n disputatio in Lausanne plaasgevind. Farel het die geleentheid geopen en afgesluit met prediking wáarin hy tien artikels vir bespreking voorgestel en verdedig het. Hierdie artikels was soortgelyk aan dié wat in Bern aanvaar is. Farel het 337 priesters uitgenooi om die dispuut by te woon, maar slegs 174 het gekom. Hulle kon Farel se stellings nie weerlê nie. Interessant genoeg het Johannes Calvyn ook die dispuut bygewoon, maar hy het net aan die gesprek deelgeneem toe die leer oor die transsubstansiasie en die teenwoordigheid van Christus by die nagmaal aan die orde gekom het. Dit was Farel wat hier die woord ten behoewe van die Kerkhervorming gevoer het (Cochrane 1966:113).

Wat inhoud betref, staan die Lausanne Artikels op die nou reeds bekende beginsel dat die Heilige Skrif leer dat daar slegs een manier is waarop die regverdiging geskied, en dit is deur die geloof in Jesus Christus wat eens en vir altyd die volmaakte offer aan die kruis gebring het (die sola fidei beginsel). Christus word bely as enigste Hoof en Heer van die Kerk, teenoor die pous. Verder is die Lausanne Artikels gemik teen die Rooms-Katolieke sakramente, seremonies, beeldeaanbidding en gebruike.

\section{DIE GENEEFSE GELOOFSBELYDENIS VAN 1536 (GENÈVE)}

Guillaume Farel het sedert 1532 die Kerkhervorming in Genève bevorder. Hy het reeds in 1535 daarin geslaag om die Raad van Tweehonderd te oortuig om die RoomsKatolieke mis af te skaf. Nadat die Rooms-Katolieke Kerk se invloed en beheer oor kerklike sake verbreek is, het daar 'n kerklike vakuum ontstaan. Daar was geen kerklike organisasie nie, en daarom het die owerheid grootliks die gang van kerklike sake beheer. Die owerheid was die Kerkhervorming goedgesind, en het die Reformatoriese predikers ondersteun. Daar was egter geen belydenisskrif wat as norm vir die prediking gegeld het nie, behalwe dat die owerheid bepaal het dat die predikers die evangelie 'volgens die Woord van God' moet verkondig (Cochrane 1966:117). Die gebrek aan 'n belydenisskrif, gebrek aan kerklike organisasie en gebrek aan kerklike dissipline was die redes waarom Farel in Augustus 1536 Johannes Calvyn oortuig het om na Genève te gaan.

Calvyn se invloed is dadelik gevoel. Hy het rigting aan die Kerkhervorming in Genève gegee deurdat hy die basiese geloofsfeite helder en duidelik geformuleer het. Die eerste uitgawe van sy Institusie het reeds in 1536 verskyn. Daarna het hy 'n Kategismus opgestel, wat in werklikheid 'n opsomming van die Institusie was. Hierdie Kategismus het die basis gevorm van talle ander kategismusse wat later ontstaan het, onder andere die Heidelbergse Kategismus (Cochrane 1966:118). Die Geloofsbelydenis wat Calvyn in samwerking met Farel opgestel het (vgl in die verband Cochrane 1966:119), was weer 'n opsomming van die Kategismus (Wendel 1978:52). 
Die Geloofsbelydenis is op 16 Januarie 1537 aan die Raad van Tweehonderd voorgelê, maar hulle het dit eers teen Maart 1537 aanvaar (Wendel 1978:52). Ten spyte daarvan dat die Raad dit aanvaar het, het die burgery onder leiding van die RoomsKatolieke party van Genève heelwat teenstand daarteen gebied. Die Geneefse Geloofsbelydenis is in ieder geval op 27 April 1537 in Frans gepubliseer, en 'n jaar later in Latyn.

Die Geneefse Geloofsbelydenis bestaan uit 21 artikels. Die artikels lê veral klem op die Woord van God as die enigste bron en norm van die geloof (sola scriptura); die totale verlorenheid van die mens (erfsonde); redding, regverdiging en wedergeborte kom deur Jesus Christus alleen; die mens ontvang al hierdie gawes alleen omdat God genadig is (sola gratia); die manier hoe ons deel kry aan die genade van God is deur die geloof (sola fidei); verder word die sakramente, die kerk, die ampte, die dissipline en die owerheid uiteengesit. Wat die kerk betref, kom die bekende standpunt na vore dat die ware kerk daar is waar die evangelie reg en suiwer verkondig word, en word verklaar dat die Rooms-Katolieke Kerk die 'die sinagoge van die duiwel' is (vgl die teks in Cochrane 1966:120-126).

\section{DIE EERSTE SWITSERSE GELOOFSBELYDENIS VAN 1536}

Pous Paulus III het in 1536 afgekondig dat 'n Konsilie in die loop van 1537 in Mantua gehou sou word. Hierdie poging was 'n mislukking - dit sou die'pous eers in 1545 geluk om 'n Konsilie in Trente byeen te kry (Bakhuizen vd Brink 1980:81, 221). Die verskillende Reformatoriese groepe was egter onder die indruk dat daar wel 'n konsilie in 1537 sou plaasvind en hulle wou baie graag voor hierdie konsilie met 'n eenduidige en klinkklare formulering van die ware geloof vorendag kom. Verder wou die teoloë (veral Bucer) van die Duitssprekende Switserse stede Zürich, Bern, Schaffhausen, Mühlhausen, Biel, St.Gall, Basel en Straatsburg eenheid met die Lutherane bewerkstellig (Cochrane 1966:97). Dit is opvallend dat die Franssprekende stede van Genève en Lausanne nie hierby betrokke was nie - hoofsaaklik as gevolg van die politieke spanning met Frankryk. Daarom het hulle (soos bo vermeld) in die loop van 1536 hulle eie belydenisskrifte geformuleer.

Die Duitssprekende stede se kerke en owerhede het almal afgevaardigdes na Basel gestuur, waar hulle op 30 Januarie 1536 in 'n konvent byeengekom gekom het. Die Konvent van Basel het Bullinger, Myconius, Leo Jud, Megander en Grynaeus aangewys om 'n geloofsbelydenis op te stel. Bucer en Capito het veral ten opsigte van die nagmaal meegewerk aan die formulering van die artikels (Cochrane 1966:97). Die komitee het die artikels geformuleer, wat onmiddelik in Latyn gepubliseer is en op 4 Februarie deur al die afgevaardigdes onderteken is. Leo Jud het die Duitse vertaling 
van die Eerste Switserse Belydenis behartig. Die afgevaardigdes van die verskillende stede het weer op 27 Maart 1536 vergader - die keer sonder die teoloë - en hulle het die Geloofsbelydenis eenparig aanvaar.

Interessant genoeg het Loo Jud in die Duitse teks 'n byvoegsel wat (vry vertaal) soos volg lui:

Met hierdie artikels wil ons geensins 'n enkele geloofsrëel aan alle kerke voorskryf nie. Ons erken immers geen geloofsreël as die Heilige Skrif nie. Wie dan ook al hierdie Geloofsbelydenis aanvaar, al sou hy ander terminologie gebruik as dié wat in die Geloofsbelydenis gebruik word, kan nieteenstaande beskou word as in ooreenstemming met ons. Ons is in die eerste plek begaan oor die saak (van die geloof) en die waarheid, en nie oor woorde nie. Ons gee dus aan elkeen die vryheid om die terminologie te gebruik wat die beste geskik is om in sy kerk te gebruik, en ons behou die reg om in vryheid onsself te verdedig teen 'n verdraaiing van die ware betekenis van hierdie Belydenis. Ons het van hierdie terminologie in die teenswoordige tyd gebruik gemaak, om daardeur ons geloofsoortuigings oor te dra.

(in Böckel 1847:116)

Hieruit word dit duidelik dat daar gepoog is om die Lutherse en Switserse groepe met mekaar te versoen deur verskille as 'n saak van terminologie en woorde te teken. Aanvanklik het Luther die Eerste Switserse Geloofsbelydenis met groot entoesiasme aanvaar. In 1544 het Luther - tot ontsteltenis van Melanchthon - in sy uiteensetting van die sakramente 'n baie skerp aanval geloods teen die Geloofsbelydenis. Ten spyte van die Lutherse invloed in die Eerste Switserse Geloofsbelydenis het dit misluk as poging om die Switserse en Lutherse groepe te verenig. Dit het egter daarin geslaag om die Duitssprekende Hervormde kerke in Switserland te verenig, en dit het ook die basis gevorm van die Tweede Switserse Geloofsbelydenis van 1566 (Cochrane 1966:98).

Inhoudelik is die artikels van die Eerste Switserse Geloofsbelydenis breedvoeriger uitgewerk as enige van die vorige geloofsbelydenisse wat in Duitssprekende Switserland ontstaan het. Die Geloofsbelydenis bestaan uit 27 artikels. Die eerste vyf artikels handel oor die Heilige Skrif, en word die genoegsaamheid en volkomenheid van die Skrif uiteengesit. Die beginsel van sola scriptura kom ook hier baie duidelik na vore. Interessant genoeg word hier ook die beginsel geformuleer dat die Skrif in terme van die Skrif self geïnterpreteer moet word. Artikels 7 tot 11 fokus op die mens en sy erfsonde. Opvallend genoeg erken Artikel 9 die mens sy vryheid van keuse, of anders die vrye wil. Tog word gesê dat die mens nie die goeie kan doen sonder die verligting van 
die Heilige Gees nie. Artikels 11 tot 13 handel oor die verlossingswerk van Jesus Christus, 14 tot 19 handel oor die kerk, 20 tot 22 handel oor die sakramente en die laaste vyf artikels oor verskillende sake soos die huwelik, owerheid en so meer.

Dit is duidelik uit die formulering van die verskillende artikels dat daar na twee kante gekyk is: Aan die een kant is teenoor die Rooms-Katolieke leer geformuleer, en aan die ander kant is so geformuleer dat dit aanvaarbaar sou wees vir die Lutherane. Artikel 22 (wat oor die nagmaal handel) sê egter dat die liggaam en bloed van Christus nie op 'n natuurlike wyse in die brood en wyn teenwoordig is nie. Dit was juis teen hierdie formulering wat Luther later te velde sou trek en sou veroorsaak dat die Eerste Switserse Geloofsbelydenis nie daarin geslaag het om eenheid tussen die Switserse en Lutherse kerke te bewerkstellig nie (vgl die teks in Cochrane 1966:100-111).

\section{DIE FRANSE GELOOFSBELYDENIS (CONFESSIO DE FOY VAN 1559)}

Vanweë die ingrype deur die owerheid, veral tydens die Bloedbruilof van Parys in 1572, is Frankryk vandag nie 'n Protestantse land nie, maar oorwegend Rooms-Katoliek. Tog is dit so dat baie kernsake van ons Reformatoriese belydenis sy oorsprong in Frankryk het. Die Franse Kerkhervormers is wreed vervolg en uitgewis, en daarom is dit veral aan Calvyn te danke dat die Franse denke behoue gebly het en versprei het na baie lande.

Jacques Le Fevre d'Etaples (1455-1537), 'n professor aan die Sorbonne, het reeds in 1530 die Bybel in Frans vertaal, en hy het selfs voor Luther en Zwingli geleer dat die Bybel die hoogste gesag en norm in geloofsake is, en tweedens dat regverdiging alleen deur die geloof plaasvind. Een van sy studente, Melchior Wolmar, was professor in Grieks in Bourges, en hy was op sy beurt weer een van Calvyn se dosente. Een van sy ander studente was Petrus Olevitanus, 'n familielid van Calvyn. Hy het self ook 'n Franse vertaling van die Bybel in 1535 in Neuchatel gepubliseer. Uit hierdie kring van geleerdes kom ook persone soos Guillaume Farel, Pierre Viret, Jean Cauvin (Johannes Calvyn) en Theodor Beza (Cochrane 1966:137).

Die Franse Protestante het teen 1555 ongeveer 400000 getel - maar hulle is deurlopend vervolg en uitgewis. Dit het vanselfsprekend die nood aan 'n geloofsbelydenis akuut gemaak, want hulle moes polemies/apologeties hulleself kon verdedig. Daarom is dit geregverdig om te beweer dat sommige geloofsbelydenisse van die Kerkhervorming in die gloed van die brandstapel ontstaan het. Vir die Hervormers van die sestiende eeu was die geloofsbelydenisse nie ' $n$ akademiese spel of geleerde gesprek nie dit was deel van hulle eksistensiele worsteling om 'n bestaan te maak te midde van wrede vervolging. Tegelykertyd was dit 'n stryd om waarlik kerk van Christus te wees. Deur die formulering van die belydenis, het die Hervormde kerk ook in 'n sekere sin gestalte aangeneem (Jahr 1964:14). 
As gevolg van die vervolging in Frankryk het Calvyn (en talle ander Franse) uitgewyk na die Franssprekende dele van Switserland en die Nederlande. Verskeie briewe is van Franse Hervormers aan Calvyn gerig, om hom te vra om vir die Franse kerk 'n geloofsbelydenis op te stel. Van die Hervormers wat in Frankryk gebly het, het verskeie pogings aangewend om ' $n$ geloofsbelydenis te formuleer. Een voorbeeld hiervan is Jean du Bordel, wat in 1557 'n geloofsbelydenis opgestel het (Jahr 1964:18). Dit was nie baie suksesvol nie. Calvyn wou eers nie 'n geloofsbelydenis opstel nie, omdat hy van mening was dat dit nooit die werk van een mens kan wees nie (Gerrish 1963: 128). Nadat die voorsitter van die Paryse Sinode, Francois de Morel, Calvyn gesmeek het om voort te gaan met die opstel van 'n geloofsbelydenis, het hy ingestem (Jahr 1964:19) en het hy dit in samewerking met Beza en Viret opgestel (Cochrane 1966: 138).

In die loop van 1559 het die vervolging van die Hervormers in Frankryk tydelik tot bedaring gekom, en dit het geleentheid gebied dat die Sinode van Parys weer sitting kon neem, en wel op 23 Mei 1559. Die Sinode het bestaan uit twintig afgevaardigdes wat twee-en-sewentig gemeentes verteenwoordig het. Hulle het in 'n private woonhuis vergader. Die Confessio de foy, wat Calvyn in Geneve opgestel het en uit vyf-en-dertig artikels bestaan het, is in behandeling geneem. Die Sinode het die eerste twee artikels herskryf, met die gevolg dat die Confessio de foy tans uit veertig artikels bestaan. Die Confessio de foy is goedgekeur, in 1560 as apologetiese geskrif aan die koning van Frankryk voorgelê en tydens die Franse Sinode van 1571 is dit finaal onderskryf deur al die Hervormde kerke en gemeentes in Frankryk.

Interessant is die verandering wat die Sinode van Parys van 1559 aan die eerste twee artikels aangebring het, in vergelyking met die artikels soos Calvyn dit opgestel het. In Artikel 2 van die belydenis lees ons dat God Hom nie net deur sy Woord aan die mens openbaar nie, maar ook deur die natuur. Dit is ook so na die Nederlandse Geloofsbelydenis oorgedra. Wat inhoud betref is daar talle ooreenkomste met die (aan ons) beter bekende Nederlandse Geloofsbelydenis.

\section{NEDERLANDSE GELOOFSBELYDENIS VAN 1561 (DOORNIK)}

Die historiese agtergrond van die Nederlandse Geloofsbelydenis (NGB) loop hand aan hand met die geskiedenis van die dokument se outeur, Guy de Breye (Guido de Brès). De Brès is in die opstel van die NGB bygestaan deur Adrianus Saravia, Herman Moded en $G$ van Wingen. Dit is egter duidelik dat De Brès die hoofaandeel aan die opstel van die NGB gehad het (Pont 1994:57). 
De Brès is in 1522 te Mons (of in Nederlands: Bergen), in die suidelike deel van Nederland, gebore (Polman s a:27). Sy sorgvuldige studie van die Bybel bring hom in konflik met die Rooms-Katolieke Kerk. In 1548 verlaat hy Mons, omdat die Hervormers in die stad wreed vervolg is. Hy vlug na Engeland, waar hy begin om teologie te studeer. In Engeland kom hy in aanraking met belangrike Kerkhervormers soos Bucer, Johannes à Lasco, Marten Micron en Datheen. In 1542 keer hy terug, en vestig hom in Rijssel. Daar begin hy die evangelie preek, en publiseer hy sy eerste teologiese werk Le Bastion de la Foy Crestienne ..., 'n publikasie wat duidelik laat blyk dat hy 'n kenner van die Patristiek was (Pont 1994:55). As gevolg van vervolging vlug hy, swerf hy rond en beland hy uiteindelik by Calvyn in Geneve, waar hy verder teologie studeer. In 1559 keer hy terug na Nederland, en tree in 1560 in die huwelik. Hy woon in die omgewing van Doornik, en daar begin hy die 'ondergrondse' kerk op te bou, omdat eredienste en vergaderings in die geheim gehou moes word. Spoedig was hy een van die leiersfigure onder die Hervormers in Nederland.

Teen 1561 het die vervolgings in Doornik toegeneem, en moes De Brès weer vlug. Maar eers het hy 'n pakkie oor die muur van die kasteel in Doornik gegooi. In die pakkie was die NGB en 'n brief gerig aan die Spaanse koning (Fillips II), wat oor Nederland regeer het. Op daardie stadium was daar juis twee koninklike kommissarisse (d'Assonleville \& De Blasere), asook die militêre bevelvoerder (Floris de Montigny) van die landvoogdes Margaretha in die kasteel. Hierdie manne is na Nederland gestuur om ondersoek in te stel na die godsdienstige woelinge in die gebied (Bakhuizen van den Brink 1940:11). Hulle het wel die pakkie van De Brès in ontvangs geneem, maar dit is sterk te betwyfel of dit ooit by die Spaanse koning - vir wie dit bedoel was - uitgekom het (Bakhuizen van den Brink 1940:11). In elk geval is die NGB in die loop van 1561 in Frans gepubliseer, in 1562 in Nederlands en in 1581 in Latyn. Die verskillende tekste is male sonder tal herdruk. Die NGB het dus wyd bekend geword, ten spyte daarvan dat die owerheid die eksemplare wat hulle kon vind so vinnig as moontlik vernietig het.

Die Spaanse koning was sterk Roomsgesind, en dit het uiteraard konflik tussen die Nederlandse Hervormde Kerk en die owerheid meegebring. Soos uit die voorafgaande beskrywing reeds duidelik geword het, moes die Hervormers van die sestiende eeu die Kerkhervorming en die formulering van die belydenisskrifte in samewerking met die owerhede deurvoer. Kerklike sake is indertyd deur wetgewing van die owerheid deurgevoer. Dit was ook die owerhede wat die Hervormers vervolg het - omdat die Kerkhervorming nie net 'n suiwer kerklike aangeleentheid was nie, maar inderdaad die landswette oortree het. Fillips II het 'n buitengewoon wrede vervolgingsveldtog teen die Nederlandse Hervormers ingestel. Sommige bronne meen dat daar meer Nederlandse martelare in die sestiende eeu gesterf het, as in die hele res van die geskiedenis van die Christendom. 
Die NGB is waarskynlik al gedurende 1563 deur 'n geheime sinode van die Nederlandse Hervormde Kerk (die Kerk onder die Kruis) as geloofsbelydenis aanvaar. Die Sinode van Antwerpen het dit in 1565 volledig hersien en as belydenis aanvaar. De Brès is in 1566 na Antwerpen beroep, en vandaar gaan hy na Valenciennes. Angesien die stad al openlik Protestants was, het hy gereeld in die openbaar gepreek. Valenciennes word in 1567 deur Rooms-Katolieke magte verower, en De Brès word saam met ' $n$ ander Reformatoriese predikant, Peregrin de la Grange, op 31 Mei 1567 tereggestel (Pont 1994:56).

As ' $n$ mens die teologiese agtergrond van die NGB wil peil, moet 'n mens raaksien dat die NGB aan die hand van die Franse Geloofsbelydenis opgestel is, wat, soos ons reeds gesien het, deur Calvyn opgestel is en deur die Sinode vn Parys verwerk is. Op die wyse het die denke en teologie van Calvyn via die NGB formeel inslag gekry in die Nederlandse Hervormde Kerk. Die NGB verteenwoordig 'n sorgvuldige samevatting van Calvyn se denke en teologie (Pont 199457).

Die NGB word gekenmerk aan sy baie sterk Skrifbeskouing. Na 'n paar inleidende artikels oor die openbaring (waarin die Sinode van Parys nagevolg word), kom die standpunt van Calvyn in artikel 7 baie sterk na vore: 'Ons glo dat hierdie heilige Skrif die wil van God volkome bevat en dat alles wat die mens moet glo tot saligheid, genoegsaam daarin geleer word ....' Daarmee word die primaat van die Skrif bo die belydenisskrifte en dogma van die kerk vasgestel, en moet die belydenisskrifte ook in ooreenstemming met die Skrif wees. In artikel 9 word gestel dat die drie belydenisse van 'die Apostels, Nicea en Athanasius' aanvaar word - met die implikasie dat dit in ooreenstemming is met die Heilige Skrif (vgl die teks in Bakhuizen van den Brink 1940:75). Verder kom die beginsels van sola gratia en sola fidei baie sterk na vore. Jesus Christus, en sy volkome verlossingswerk, vorm die hart van die belydenisskrif. In die opsig is dit 'n klassieke voorbeeld van Calvinistiese denke, maar meer - dit is ook die hoogtepunt in die ontwikkeling van die Reformatoriese belydenisskrifte van die sestiende eeu.

As ' $n$ mens die NGB in konteks wil verstaan, moet 'n mens dit veral as 'n apologetiese geskrif beskou. Uit die begeleidende brief wat aan Fillips II gerig is, word dit duidelik dat die NGB as 'n apologetiese geskrif bedoel was. In die brief pleit De Brès om die koning sè genade. Verder wou hy die Hervormers se beskouings uiteensit en verdedig. In sy uiteensetting van hulle verhouding met Fillips II maak De Brès, in lyn met die Franse Geloofsbelydenis soos geformuleer deur die Sinode van Parys, van twee beginsels gebruik: die natuurreg en die Woord van God. Daarom sê hy dat die 'verborge getuienis van hul gewete en die Woord van God' hulle leer dat rebellie en opstand teen die koning 'n gruweldaad is (vgl teks in NHKA Diensboek 1987:128). 
De Brès sê verder in sy brief aan die koning dat die owerhede deur God ingestel is, en dat dit deel van God se ordening van die wêreld is. Hierin sluit hy by Calvyn se opvatting van 'orde' aan (Dreyer 1995:15-25). Daarom is elkeen wat in opstand teen die owerheid is, in opstand teen die ordening van God. De Brès wou Filips II verseker dat die Hervormers nie rewolusie of rebellie in die oog het nie, maar die ware geloof. Dit kan aanvaar word dat die Nederlandse Hervormers bereid sou wees om onder Filips II se regering te staan, solank as wat die koning hulle die vryheid sou toelaat om die ware geloof te beoefen. Dit verklaar waarskynlik waarom Willem van Oranje aanvanklik nie teen Filips II in opstand wou kom nie.

De Brès beroep hom verder op die humanitas van die koning, naamlik dat hy in sagmoedigheid teenoor sy volk moet optree. De Brès se Calvinisties-teokratiese visie op die struktuur van die gemeenskap word verder duidelik in Artikel 36 van die NGB verwoord. Hierdie artikel het in die Nederlandse en Suid-Afrikaanse geskiedenis 'n besondere groot invloed uitgeoefen, veral op die Afrikaner se denke oor die verhouding tussen kerk, volk en owerheid (vgl Dreyer 1995).

\section{DIE HEDELBERGSE KATEGISMUS VAN 1563}

Toe die Hervormdgesinde Frederik III in 1559 keurvors van die Palts geword het, het daar in die digbevolkte en voorpoedige keurvostedom groot verwarring op godsdienstige gebied geheers (Oberholzer 1986:1). Die stryd tussen die Rooms-Katolieke Kerk en die Protestante het hewig gewoed, en tegelykertyd het daar na Luther se dood in 1546 groot onenigheid tussen die Lutherane losgebreek. Daarby het die Doperse beweging en die Spritualiste ook beroering veroorsaak. Dit het verder gelyk of die Lutherane en Calviniste in kompetisie was oor wie die meeste mag en invloed kon verkry. Daar het rondom die nagmaal 'n hewige stryd gewoed, onder leiding van die Lutherse professor Tilemann Heshusen aan die een kant, en die Calvinistiese diaken Wilhelm Klebitz aan die ander kant.

Frederik III het persoonlik in die nagmaalstryd ingegryp - nie net ter wille daarvan dat dit politieke stabiliteit in sy keurvorsdom sou bring nie, maar ook omdat dit vir hom persoonlik 'n baie belangrike saak was. Hy was self 'n Rooms-Katoliek wat na sy huwelik met 'n Protestantse meisie tot die Kerkhervorming oorgegaan het. Teen die tyd wat hy die troon bestyg het, was hy 'n oortuigde Lutheraan. Die gevolg was dat hy Melanchthon van Wittenberg gevra het om hom te adviseer om die nagmaalstryd te besleg. Die uiteinde daarvan was dat hy beide Heshusen en Klebitz ontslaan het. Verder het hy in 1560 die formulering van Melanchthon - wat vir die Lutherse sowel as die Calvinistiese standpunt oor die nagmaal ruimte laat - na 'n disputatio aanvaar en laat invoer as norm in die keurvorsdom. 
Die re-organisasie en hervorming van die kerk kon egter nie deurgevoer word sonder ' $n$ behoorlik gefundeerde belydenisskrif nie. Daarom besluit hy om ' $n$ kategismus te laat opstel wat die standaard leerboek en norm vir die prediking in die Palts sou wees. Hy vra dan vir Zacharias Ursinus, die 28 -jarige professor in Dogmatiek van die Universiteit van Heidelberg, om so 'n kategismus op te stel. Ursinus het aan die Universiteit van Wittenberg studeer en tydens sy studie het hy sterk onder die invloed van Melanchthon gekom. Daarna vertrek hy op 'n studiereis na Frankryk, waar hy Grieks en Hebreeus studeer. Op die reis ontmoet hy ook vir Calvyn, en kom hy ook onder sy invloed (Oberholzer 1986:2). Hy studeer ook in Zürich, waar hy onder die invloed van Bullinger kom. Hy word hierna deur Frederik III uitgenooi om aan Heidelberg sy studies te voltooi - waar hy dan ook promoveer en begin lesings gee in Dogmatiek.

Ursinus het nie alleen aan die Kategismus gewerk nie. 'n Paneel teoloë is aangewys wat sy voorleggings bespreek het en geëvalueer het. Oorspronklik was daar 323 vrae en antwoorde, wat verkort en verwerk is tot die dokument wat ons vandag as die Heidelbergse Kategismus ken. Navorsing het aangetoon dat Ursinus wyd navorsing gedoen het, en die kategismusse van Melanchthon, Zürich, Geneve, Emden, Straatsburg, Beza, Calvyn en Bullinger gebruik het. So het die Heidelbergse Kategismus verteenwoordigend geword van 'n wye spektrum van Reformatoriese teologie.

Die voltooide Kategismus is op 13 Januarie 1563 aan 'n sinode wat in Heidelberg vergader het, voorgelê vir goedkeuring. Dit is sonder wysiging aanvaar, hoewel die Lutherse superintendente teen sommige artikels beswaar aangeteken het. Ten spyte daarvan het Frederik III die Kategismus se voorrede onderteken, en is dit op sy bevel in die Palts ingevoer. Hy het eksemplare van die Kategismus aan verskeie keurvorste gestuur, asook aan Maximiliaan II, die latere Duitse keiser. Op voorstel van Caspar Olevianus is nog ' $n$ vraag ingevoeg (vraag 80 ), wat handel oor die onderskeid tussen die nagmaal en die Rooms-Katolieke mis. Dit is gedoen omdat die dekrete wat die Konsilie van Trent in hierdie tyd uitgevaardig het, die Hervormers se nagmaalstandpunt gekritiseer het.

Die Heidelbergse Kategismus en die Kerkorde wat Frederik III ingevoer het, is nie algemeen in die Palts aanvaar nie. Verskillende Lutherse ampsdraers is uit hulle ampte onthef, voordat die Kerkhervorming volledig in die Palts deurgevoer kon word. In die Opper-Palts was Frederik III se pogings tot 'n eenvormige Kerkhervorming 'n mislukking, omdat daar te veel weerstand was van die Lutherse kerke en ampsdraers. Die Kategismus het ook 'n hele akademiese strydgesprek ontketen, met Lutherse teoloë aan die een kant en Ursinus en Olevianus aan die ander kant. Hierdie besware het veral gehandel oor die Kategismus se twee-natureleer en nagmaalsopvatting. 
Die Lutherane se teenkanting teen die Kategismus was so erg dat die saak deur die Ryksdag van Augsburg in 1566 bespreek is. Maximiliaan II en ander keurvorste wou hê dat die Godsdiensvrede van 1555 net van toepassing gemaak moes word op dié wat die Augsburgse Konfessie onderskryf. As die besluit deurgevoer sou word, sou dit beteken dat die Heidelbergse Kategismus moes verdwyn. Daar was egter heelwat steun van ander keurvorste vir die Heidelbergse Kategismus, en daarom is die besluit nie deurgevoer nie en het die Kategismus as belydenisskrif vir die Palts behoue gebly. Op die Ryksdag het Frederik onder andere van die Kategismus gesê: 'Wat my Kategismus betref, ek bely dit. Dit is in die kantlyn so met fondamente uit die Heilige Skrif verskans, dat dit onomstootlik moet bly en sal, so hoop ek, nog langer onomstootlik bly (vertaal uit Lippischen Landeskirche 1938:163).

Hierdie teenkanting teen die Heidelbergse Kategismus in die gebiede oos van die Palts, het veroorsaak dat die Kategismus meer invloed na die weste uitgeoefen het, en veral in Nederland. In 1563 is daar reeds twee Nederlandse vertalings van die Kategismus gemaak. Hierdie vertalings het spoedig groot invloed in die Nederlande uitgeoefen (Bakhuizen van den Brink 1980:270). Die Kategismus is byvoorbeeld by al die herdrukke van Datheen se Psalms ingebind, en die Konvent van Wesel het reeds in 1568 besluit dat alle ouderlinge moet instem met die Nederlandse Geloofsbelydenis en die Kategismus (Pont 1981:81). Daaropvolgende sinodes in Nederland het soortgelyke besluite geneem. In die volgende eeue sou die Heidelbergse Kategismus wêreldwyd (ook in Suid-Afrika) groot invloed in Reformatoriese kerke uitoefen.

Dit is opvallend, as 'n mens die voorrede van die Kategismus lees, dat Frederik III die verantwoordelikheid aanvaar om nie net die land goed te regeer nie, maar ook om die burgers van sy land te lei tot die regte geloof in God. In die voorrede word gesê:

Daartoe gemaan deur die Goddelike Woord en ook deur die natuurlike plig en gesindheid, het ons (pluralis majestatis - WAD) ons voorgeneem om die amp, beroep en regering wat God aan ons opgedra het, uit te voer nie alleen met die oog op 'n vreedsame en rustige bestaan nie, maar ook met die oog op die handhawing van die ingetoë, opregte en deugsame gedrag en lewe van ons onderdane, vernaamlik egter om hulle steeds meer te lei en te bring tot regskape kennis van en eerbied vir die Almagtige en sy saligmakende Woord, as die enigste fondament van alle deugde en gehoorsaamheid .... Die jeug moet moet van die begin af in die eerste plek opgevoed word in die suiwere en ook eenvormige leer van die heilige evangelie en in die regskape kennis van God, en voortdurend daarin geoefen word.

(Teks aangehaal uit Diensboek van die NHKA 1987:166-167) 
Uit hierdie aanhaling word dit duidelik dat die Kategismus in die eerste plek bedoel is as 'n leerboek vir die jeug tydens kategese. Tegelykertyd is ook die ouer mense tydens die prediking geleer uit die Kategismus, veral omdat die meeste onder die Rooms-Katolieke Kerk opgegroei het en geen kennis van die Bybel gehad het nie. Dit Kategismus het egter ook as belydenisskrif gedien. So word dit duidelik dat die belydenisskrif uit die kerklike praktyk gebore is, uit die nood van die prediking, kategese en die noodsaaklikheid dat die kerk in die wêreld moet getuig van die waarheid wat hy bely. As belydenisskrif het dit ook gedien om die eenheid van die geloof te bewaar. In die teokratiese denke van die setiende eeu was dit ook nie vreemd dat dit juis die owerheid was wat ten behoewe van die kerk ingegryp het, om die eenheid in die geloof te bewerkstellig nie. Die Kategismus moes ook daartoe dien om deugsame en godvresende burgers vir die keurvorsdom van Frederik III te lewer.

\section{DIE DORDTSE LEERREËLS VAN 1618/1619}

Die historiese agtergrond van die Dordtse Leerreëls is die kerklike stryd wat aan die einde van die sestiende en begin van die sewentiende eeu in Nederland uitgebreek het. Politieke verskille tussen die kerklike groeperinge het die situasie aansienlik vererger. Die kerklike stryd het gehandel oor die uitverkiesingsleer (predestinasieleer). Jacobus Arminius (1560-1609), hoogleraar aan die Universiteit van Leiden, se opvatting oor die uitverkiesing was nie so streng soos sy ampsgenoot Franciscus Gomarus (1563-1641) nie. Rondom Arminius het die sogenaamde Rekkelijke partij ontstaan. Gomarus het Arminius en die Rekkelijkes van Pelagianisme beskuldig (Bakhuizen van den Brink 1980:227). Beide het ook daarop aangedring dat 'n algemene sinnode gehou moet word om oor die saak te besluit.

Arminius het in sy uiteensetting van die uitverkiesing klem gelê op die vrye wil van die mens, en die verantwoordelikheid van die mens om God se genade aan te neem. Hy meen dat die uitverkiesing van God inhou dat Hy die mens in Christus kies om deel te hê aan sy genade, maar dat God dit doen terwyl Hy rekening hou met die geloof en die mens se vrye aanneme van sy genade. Volgens Arminius sien God die geloof van die mense vooruit, en op grond daarvan word hy/sy uitverkies om deel te hê aan God en aan die ewige lewe. Daarteenoor het Gomarus die standpunt verdedig dat God reeds voor die skepping besluit het wie Hy wil uitkies en wie Hy wil verwerp. Verder leer hy dat ook die geloof van die mens 'n gawe van God is aan sy uitverkorenes. Na die twee geleerde here se dood, is die stryd deur verskillende van hulle ondersteuners verder gevoer. 
Arminius se volgelinge is mettertyd Remonstrante genoem, omdat Wtenbogaert ('n leerling van Beza, hofprediker van Prins Mauritz en leier van Arminius se volgelinge) in 1610 ' $\mathrm{n}$ remonstrantie (versoekskrif) by die owerheid ingehandig het waarin hy stel dat die Nederlandse Geloofsbelydenis en die Heidelbergse Kategismus altyd aan hersiening onderwerp moet word wanneer sinodes vergader (Pont 1994:87). Die belangrike dryfveer agter die remonstrantie was die feit dat hy van die belydenisskrifte verskil het, veral ten opsigte van die uitverkiesingsleer, en dat hy van die owerheid verwag het om die persone te beskerm wat verskil van die leer van die belydenisskrifte. Daarmee is die owerheid volledig betrek in die kerklike stryd. Geleidelik het die sake waaroor die kerklike stryd gegaan het, uitgekristalliseer: Leerstellig het dit oor die uitverkiesing gegaan, en kerkordelik oor die bevoegdheid van die owerheid om in kerklike sake in te meng.

In artikel 1 van die remonstrantie (vgl die teks in Pont 1994:87-95) word gestel dat God, deur 'n ewige onveranderlike besluit in Jesus Christus, voor die grondlegging van die werreld, besluit het om uit die gevalle, sondige mensheid, daardie mense in Christus, ter wille van Christus en deur Christus salig te maak, wat deur die genade van die Heilige Gees in Hom, sy Seun, glo en wat deur hierdie genade in daardie geloof en geloofsgehoorsaamheid tot die einde sou volhard. Later het die Remonstrante hierdie punt nader verklaar deur alles afhanklik te maak van die geloof en vrye keuse van die mens. Daarmee het die mens se geloof (wat vooraf deur God gesien is) en keuse die voorwaarde van verlossing geword. So word die geloof en keuse van die mens nie die gevolg van die uitverkiesing nie, maar die oorsaak van die uitverkiesing. Dit sou ook beteken dat die mens God se genade kan weier.

Die leerstryd het nog meer van 'n politieke dimensie verkry, nadat Wtenbogaert in 1610 ' $n$ tweede brosjure die lig laat sien het met die titel Tractaat over het ambt en gezag der overheid (Pont 1994:97). In die brosjure verdedig hy sy standpunt dat die owerheid die reg het om in kerklike sake in te gryp, aangesien die owerheid meer gesag het as enige kerklike vergadering. Hiermee het hy in wese Coolhaes se standpunte herhaal. Verskeie plaaslike owerhede het op grond van hierdie brosjure, hulle die reg toegeeien om in die kerklike stryd in te gryp.

Die leerstellige en politieke twis het so in felheid toegeneem, dat dit stelselmatig die stabiliteit van sommige Nederlandse provinsies bedreig het. Die twee teenoorgestelde groepe het mettergaan as die Remonstrante en Contra-Remonstrante begin bekend staan. 'n Groot getal politieke en teologiese strydgeskrifte is orals versprei. In die loop van Julie 1617 het prins Mauritz in die leerstryd ingegryp, deur nie meer sy hofprediker, Wtenbogaert, se eredienste by te woon nie, maar eerder Contra-Remonstrante eredienste by te woon. Hiermee het hy die owerheid openlik aan die Contra- 
Remonstrante verbind. Hy het ook van die Remonstrante uit hulle politieke ampte ontslaan, en selfs laat teregstel (Dreyer 1995:42-43). Uiteindelik gee hy opdrag dat 'n algemene sinode moet vergader om die saak te besleg.

Die Nasionale Sinode van Dordrecht wat in die jare 1618/1619 sitting geneem het, is dus in opdrag van Prins Mauritz en die Staten - Generaal van Nederland byeengeroep, met die spesifieke doel om die leerstryd wat tussen die Remonstrante en ContraRemonstrante gewoed het, op te los. Omdat die Sinode in diepte oor die leer van die Nederlandse Hervormde Kerk sou handel, is 23 uitstaande teoloë uit Engeland, Hessen, die Palts, Bremen, Emden, Genève en ander dele van Switserland genooi om dit saam met die Nederlandse afgevaardigdes by te woon. Uit die Nederlandse kerk is 37 predikante, 19 ouderlinge en 5 hoogleraars na die sinode afgevaardig. Die owerheid het ook 18 kommissarisse aangewys wat die sinode bygewoon het. Dit het van die sinode byna iets soos 'n Reformatoriese ekumeniese konsilie gemaak (Pont 1981:168).

Die sinode het in twee duidelike fases verloop: Die eerste fase begin met die opening van die sinode op 13 November 1618, en eindig 154 sittings later op 6 Mei 1619. Tydens hierdie eerste deel van die sinode is die Dordtse Leerreëls opgestel. Hierna het die buitelandse teoloë vertrek, en op 13 Mei 1619 het die Nederlandse afge-vaardigdes voortgegaan om die kerkordelike reëlings wat nodig was te tref. Dit het nog 26 sittings geneem, en uiteindelik is die sinode op 29 Mei 1619, tydens die 180e sitting afgesluit.

Die werksaamhede van die sinode is gelei deur vier manne van besondere kwaliteit: Johannes Bogerman ('n pastorieseun wat in Franeker, Heidelberg, Genève, Zürich, Lausanne, Oxford en Cambridge teologie studeer het en in 1633 benoem is as teologiese professor te Franeker); Hermanus Faukelius (wat teologie aan Leiden studeer het, vertaler van die Nuwe Testament en opsteller van die bekende Kort Begrip); Festus Hommius (wat teologie in Franeker, La Rochelle en Leiden studeer het, privaatdosent aan die Universiteit van Leiden en hoofopsteller van die beroemde Contra-remonstrantie) en Sebastian Damman (Pont 1981:168-169). Hierdie manne, tesame met professore Polyander en Rolandus, was verantwoordelik vir die finale verwerking Canones wat op die sitting van 23 April aan die sinode voorgelê is (Bakhuizen van den Brink 1940:35-36).

Na afloop van die Algemene sinode van Dordrecht is die Remonstrante gevra om instemming te betuig met die besluite van die sinode. Die Leerreells is deur die heie land versprei, en al die predikante moes dit onderteken. Die wat dit nie wou teken nie, is voor die klassikale vergaderings gedaag, waarna hulle uit hulle amp onthef is. Op die wyse is oor die 200 ampsdraers voor klassikale vergaderings gedaag, waarvan 80 uit die land verban is. Die 15 leiers van die Remonstrante het elk 'n akte van stilstand ontvang, wat beteken dat hulle verbied is om met hulle werk voort te gaan. Die wat geweier het, is uit die land verban of het gevangenisstraf ontvang (Pont 1994:113). 
Dit is uit hierdie kort beskrywing duidelik dat die teologiese agtergrond van die Dordtse Leerreels nie net die problematiek rondom die uitverkiesing is nie, maar ten diepste die vraag na die vrye wil van die mens. Die debat oor die vrye wil van die mens was natuurlik niks nuuts nie. In die kerkgeskiedenis is daar 'n paar opvallende hoogtepunte in die debat oor die vrye wil:

* Augustinus het aan die begin van die vyfde eeu 'n kontrovers teen Pelagius gevoer, oor die vraag of die mens nog na die sondeval 'n vrye wil het, en self kan kies tussen goed en kwaad.

* Gedurende die Middeleeue is die debat kort-kort tussen geleerdes gevoer.

* In die loop van 1524/1525 het Disiderius Erasmus vanuit sy filososofiese humanisme Luther aangevat in sy De libero arbitrio (Oor die vrye wil), waarna Luther geantwoord het met sy De servo arbitrio (Oor die gebonde wil).

* In 1552 het Johannes Calvyn en die Rooms-Katolieke geleerde, Albertus Pighius, 'n indringende debat oor die uitverkiesing en vrye wil gevoer.

* Die Remonstrante het vasgehou aan die beginsel dat die mens 'n vrye wil het, en self moet kies vir of teen God. Die Contra-Remonstrante staan baie sterk daarop dat die geloof en bekering van die mens nie die gevolg van sy eie vrye wil is nie, maar baie duidelik die gevolg van die God se uitverkiesing is.

Die Dordtse Leerreèls bestaan uit 5 hoofstukke, met hoofstukke 3 en 4 wat saamgegroepeer is. Die eerste hoofstuk handel in 18 artikels oor die Goddelike uitverkiesing en verwerping; die tweede handel in 9 artikels oor die verlossingswerk van Jesus Christus; hoofstuk 3 en 4 handel oor die verdorwendheid van die mens, sy bekering en die wyse waarop dit plaasvind; die vyfde hoofstuk handel in vyftien artikels oor die volharding van die gelowiges. Die hoofstukke word telkens afgesluit met 'n opsomming van die Remonstrante se dwalings (vgl die teks in NHKA Diensboek 1987:217252).

Wat opvallend is, is dat die verlossing van die mens, en daarom ook die uitverkiesing, baie sterk Christosentries verklaar word. Die Dordtse Leerreëls werk met 'n pessimistiese mensbeskouing. In die mens is daar niks goeds te vind nie, en self kan die mens nie tot geloof en bekering kom nie. In kort kom dit daarop neer dat die Leerreëls die vrymag en soewereiniteit van God beklemtoon. God is God. Hy kan maak soos Hy goeddink. En die klei kan die pottebakker nie verkwalik nie. 
Pont (Pont 1994:105) oordeel dat die uitverkiesingsleer in die Dordtse Leerreèls nie filosofies-deterministies verstaan moet word nie. Die uitverkiesing vind dus nie buite Christus, buite die verkondiging en buite die apostolaat van die kerk om plaas nie. Die uitverkiesing het doodgewoon te make met God se genade vir die sondaarmens wat totaal en al verlore is in sy sonde. Hoekom God sommige mense in genade uitverkies en ander nie - daaroor kan ons nie te vinnig gevolgtrekkings maak nie. Dit is God self wat die skeidslyne trek - en die mens kan nie aan God voorskryf waar Hy die skeidlyne moet trek nie. Wat die Sinode van Dordrecht wou doen, was om sorgvuldig na die Woord te luister, en te sê wat die Woord sê.

Samevattend is dit duidelik dat die Dordtse Leereëls die hoofpunte van die uitverkiesingsleer, soos dit in die Skrif na vore kom en reeds verwoord is in die NGB en die Heidelbergse Kategismus, vanuit 'n bepaalde hoek saamvat (Pont 1994:110). Daarmee is die Remonstrante se standpunte veroordeel, en is hulle uit hulle ampte afgesit. Dit moet ook in gedagte hou dat die Sinode net die remonstrantie behandel het, en daarom is die Dordtse Leerreëls nie 'n volledige teologiese uiteensetting van die leer or die uitverkiesing nie. Iets soos die regverdiging deur die geloof word nie in diepte behandel nie, en dit kan, indien die Leerreëls in isolasie gelees word, maklik 'n verwronge beeld skep. Dit bly dus noodsaaklik om die belydenisskrifte teen hulle eietydse historiese, teologiese en filosofiese agtergronde te lees.

\section{SLOTOPMERKINGS}

Die belydenisskrifte wat tydens die Kerkhervorming ontstaan het (waarvan enkeles hierbo oorsigtelik beskryf is), is historiese dokumente. As historiese dokumente moet dit binne hulle eie konteks gelees en verstaan word. Dit beteken dat die teoloog wat die belydenisskrifte wil verstaan, baie deeglik rekening moet hou met die historiese, teologiese en filosofiese agtergrond daarvan. In daardie opsig is die belydenisskrifte nie anders as enige ander historiese dokument nie, en moet in die interpretasie daarvan dieselfde hermeneutiese beginsels toegepas word as op ander historiese dokumente.

Egte hermeneutiek vind net plaas waar daar erns gemaak word met die konteks van 'n bepaalde dokument, maar ook die eietydse konteks. Wanneer die belydenisskrifte ondersoek en interpreteer word, moet daar dus met die belydenisskrifte se historiese agtergrond rekening gehou word, sowel as met die feit dat die belydenisskrifte in die huidige as belydenis van die Kerk geld.

Indien die historiese of eietydse konteks van die belydenisskrifte losgelaat word, lewer dit verskillende probleme op: 
* Aan die een kant lei dit tot 'n ortodoksisme en verstardheid in die leer van die kerk. Dit lei verder tot waninterperetasie van die belydenisskrifte, want hoewel daar groot erns gemaak word met die belydenisskrifte as sodanig, word die moeite ontsien om deur deeglike navorsing en eksegese vas te stel wat die belydenisskrifte binne hulle historiese konteks wou sê.

* Aan die ander kant lei dit daartoe dat die belydenisskrifte beskou word as antieke dokumente wat nie meer in pas is met eietydse denke en teologie nie. In hierdie benadering van die belydenisskrifte kan die eietydse insigte so dominant in die hermeneutiese proses word, dat die bedoeling van die belydenisskrifte verlore raak. Op so wyse word (dikwels onbewus) weggedoen met groot gedeeltes van die belydenisskrifte. Dit is niks anders as 'n reservatio mentalis benadering nie, waar ' $n$ teoloog wel die belydenisskrifte onderskryf omdat die kerk dit van hom/haar verwag, maar in werklikheid net dié dele van die belydenisskrifte aanvaar wat vir hom/haar aanvaarbaar is. So ' $n$ benadering doen nie net onreg aan die korrekte interpretasie van die belydenisskrifte nie, maar is oneerlik teenoor die kerk wat van sy ampsdraers verwag om die belydenisskrifte volledig te onderskryf.

Die belangrikste oorblyfsels van die verlede bestaan uit geskrewe dokumente, wat $o p$ sigself' 'n getuieniskarakter het. Dit vertel of sê iets van die verlede (Dreyer 1974:82). Die interpretasie van sulke historiese dokumente (soos die belydenisskrifte) is nie net ' $n$ suiwer teologiese aangeleentheid nie, maar moet voldoen aan die wetenskaplike en metodologiese eise van geskiedenis-as-wetenskap. In die interpretasie van die belydenisskrifte word die teoloog ook historikus, omdat die dokumente waarmee hy of sy werk, ' $n$ bepaalde geskiedenis het en ' $n$ bepaalde getuienis oor die verlede lewer.

Ten slotte moet ' $n$ mens ook besef dat die belydenisskrifte nooit bedoel was as 'n akademiese stuk rasionalisme nie. Die woord belydenis dra die betekenis van plegtige erns, van persoonlike verantwoordelikheid, van feestelike blydskap (Polman s a:7). Dit het die betekenis van openlik erken, openbare belydenis, getuienis aflè. Dit is wesenlik aan die kerk om te bely (Matt 10:32). Dit is 'n eis wat nog steeds aan elke gelowige gestel word. Die gelowige moet met sy lewe instaan vir die waarheid wat hy bely. Die belydenis van die gelowige gee deel aan die verlossingswerk van Jesus Christus (Rom 10:9, 10).

Die postmoderne denke bring egter mee dat die skeptiese Pilatus-vraag: 'Wat is waarheid'? almeer gevra word. Daarmee verword die debat oor die belydenisskrifte in 'n akademiese spel met woorde, terwyl dit in werklikheid vir die kerk en elke gelowige 'n saak van eksistensiele belang is. 


\section{Literatuurverwysings}

Bakhuizen van den Brink, J N 1940. De Nederlandsche Belijdenisschriften. Amsterdam: Uitgevers-maatschappij Holland.

1980. Handboek der kerkgeschiedenis, deel 3. Leeuwarden: De Tille B.V.

Böckel, E G A 1847. Die Bekenntnisschriften der evangelisch-reformierte Kirche. Leipzig.

Cochrane, A 1966. Reformed confessions of the sixteenth century. London: SCM.

Dreyer, P S 1974. Inleiding tot die filosofie van die geskiedenis. Pretoria: HAUM.

Dreyer, W A 1995. Kerk, volk en owerheid - 'n Hervormde perspektief. DD-proefskrif, Universiteit van Pretoria.

Gerrish, B A 1963. The faith of Christendom: A source book of creeds and confessions. The World Publishing Company.

Jackson, S M 1903. Huldreich Zwingli. G P Putnam's Sons.

Jahr, H 1964. Studien zur Überlieferungsgeschichte der Confession de foi von 1559. Neukircen-Vluyn: Neukirchener Verlag des Erziehungsvereins.

Lippischen Landeskirche 1938. Geschichte des Heidelberger Katechismus, in Der Heidelberger Katechismus. Essen.

Nederduitsch Hervormde Kerk van Afrika, 1987. Diensboek. Pretoria: Kital.

Oberhozer, J P 1986. Die Heidelbergse Kategismus, in vier teksuitgawes, met inleiding en teksvergelyking. Pretoria: Kital.

Polman, A D R s a. Woord en belijdenis, deel 1. Franeker: T.Wever.

Pont, A D 1981. Historiese agtergronde van ons kerklike reg, deel 1. Pretoria: Kital. 1994. 'n Inleiding tot die Nederlandse Kerkgeskiedenis: Van die beginjare tot 1795. Pretoria: Universiteit van Pretoria. (HTS Suppl 6.) 